Chapter 8

\title{
Policies for Sustainable Buildings
}

More and more countries are enacting policies to increase the sustainability of the building sector through the adoption of green innovations in buildings. In previous chapters, the progressive reduction of energy consumption of buildings has been pointed. Recent actions to increase the sustainability of buildings have largely been due to national and international policies. Many of these have been stimulate the diffusion of sustainable buildings worldwide in the last years. The present chapter reviews existing policies.

The first energy efficiency standards were set in Poland and France in the 1960s. Other countries followed previous standards in the 1960s (della Cava et al., 2001). However, these standards were often poorly implemented, and therefore did not have significant effects in the building industry. The first energy efficiency codes for building were set in the 1970s (Deringer et al., 2004). Since then, the variety of policies has considerably grown from regulatory and voluntary instruments in the initial phase towards financial incentives and economic instruments in the last years (IEA, 2010).

Since the 1990s, with the increasing awareness on climate change, more and more countries have introduced appliances standards, building codes, and sustainability requirements (Deringer et al., 2004). For various reasons, the effectiveness of these policy measures in reaching their goals varies significantly depending on countries, situations and policy instruments. For example, building codes have reduced energy consumption of new dwellings in U.S. by about 30\%, but a shift to sustainable buildings is still far to be reached. Similarly, sustainable buildings policies are often ineffective in developing countries (Deringer et al., 2004). In general, little understanding exists about the impact of the various policy instruments. Basing on the conclusions of previous chapters, the present chapter aims to review available policies and answer the following question: which policies could favour the adoption of green innovations in sustainable buildings?

\subsection{Review of Policies}

In the building sector, policies have often promoted through standards and codes. In Chapters 1 and 3 we discussed the recent trends for energy saving in buildings as mostly ruled by national and international policies. Table 8.1 lists some European and American acts that are actually regulating the building sector and which aim to change buildings in the next years. 
Table 8.1 European and American actions that are actually regulating the building sector.

\begin{tabular}{|l|l|}
\hline Standard and code & Requirement \\
\hline $\begin{array}{l}\text { European Directive 2010/31/EU } \\
\text { recast (European Commission, } \\
2010)\end{array}$ & $\begin{array}{l}\text { As of } 31 \text { December 2020, all new buildings are nearly } \\
\text { zero-energy buildings; } \\
\text { After } 31 \text { December 2018, new buildings occupied and } \\
\text { owned by public authorities are nearly zero-energy } \\
\text { buildings. }\end{array}$ \\
\hline $\begin{array}{l}\text { Energy Independence and } \\
\text { Security Act 2007 (EISA, 2007) }\end{array}$ & $\begin{array}{l}\text { As of 2025, all new commercial buildings must be zero } \\
\text { net energy; } \\
\text { As of } 2050, \text { all US commercial buildings must be zero net } \\
\text { energy including retrofits of pre-2025 buildings. }\end{array}$ \\
\hline $\begin{array}{l}\text { Presidential Executive Order } \\
13514 \text { Federal Office, 2009 }\end{array}$ & $\begin{array}{l}\text { As of 2020, all planning for new Federal buildings } \\
\text { requires design specifications that achieve zero net- } \\
\text { energy use; } \\
\text { As of 2015, large government buildings have to show } \\
\text { progress; } \\
\text { As of } 2015, \text { at least } 15 \% \text { of any Federal agency's existing } \\
\text { buildings and building leases above } 500 \text { m }{ }^{2} \text { must } \\
\text { conform to zero net energy and on-going improvements } \\
\text { are required. }\end{array}$ \\
\hline
\end{tabular}

However, energy codes represent only one of the policies that are actually implemented to moving to sustainable buildings. This chapter presents an overview of many other policies. Following a recent publication of the SBCI (2007), policy instruments for sustainable buildings can be classified in four categories:

- Regulatory and control mechanisms;

- Economic or market-based instruments;

- Fiscal instruments and incentives;

- Information and voluntary actions.

These policy instruments are categorised in Table 8.2, together with emission reduction efficiency of GHG, cost efficiency and special conditions for their success. Instruments are hence analysed below for their use and effectiveness.

\subsubsection{Regulatory and control mechanisms}

Control and regulatory policies are probably the most common instruments in the buildings sector (UNEP, 2007). They can be defined as institutional rules that aim to directly influence the sustainability performance by regulating processes and products used and by prohibiting or limiting the discharge of some pollutants. 
Table 8.2 Classification of Policies for sustainable building (re-adapting UNEP, 2007).

\begin{tabular}{|c|c|c|c|}
\hline Policy instruments & $\begin{array}{l}\text { Reduction } \\
\text { Efficiency }\end{array}$ & $\begin{array}{l}\text { Cost } \\
\text { efficiency }\end{array}$ & $\begin{array}{l}\text { Special conditions for success, major strengths, } \\
\text { limitations, and benefits }\end{array}$ \\
\hline \multicolumn{4}{|c|}{ Regulatory and control instruments } \\
\hline Appliance standards & High & High & $\begin{array}{l}\text { Factors for success: periodical update of standards, } \\
\text { independent control, information, communication, } \\
\text { education }\end{array}$ \\
\hline Building codes & High & Medium & Only effective if enforced and periodically updated \\
\hline $\begin{array}{l}\text { Energy efficiency } \\
\text { obligations and quotas }\end{array}$ & High & High & $\begin{array}{l}\text { Continuous improvements necessary: new energy } \\
\text { efficiency measures, short term incentives to transform } \\
\text { markets }\end{array}$ \\
\hline $\begin{array}{l}\text { Mandatory audit } \\
\text { requirement }\end{array}$ & $\begin{array}{l}\text { High, but } \\
\text { variable }\end{array}$ & Medium & $\begin{array}{l}\text { Most effective if combined with other measures such as } \\
\text { financial incentives }\end{array}$ \\
\hline $\begin{array}{l}\text { Labelling and certification } \\
\text { programs }\end{array}$ & $\begin{array}{l}\text { Medium } \\
\text { High }\end{array}$ & High & $\begin{array}{l}\text { Mandatory programs more effective than voluntary ones. } \\
\text { Effectiveness can be boosted by combination with other } \\
\text { instrument and regular updates }\end{array}$ \\
\hline $\begin{array}{l}\text { Demand-side } \\
\text { management programs } \\
\text { (DSM) }\end{array}$ & High & High & $\begin{array}{l}\text { Tend to be more cost-effective for the commercial sector } \\
\text { than for the residential sector }\end{array}$ \\
\hline \multicolumn{4}{|c|}{ Economic and market-based instruments } \\
\hline $\begin{array}{l}\text { Energy savings } \\
\text { performance contracting / } \\
\text { ESCO support }\end{array}$ & High & Medium & $\begin{array}{l}\text { Strength: no need for public spending or market } \\
\text { intervention, co-benefit of improved competitiveness }\end{array}$ \\
\hline $\begin{array}{l}\text { Cooperative } \\
\text { procurement }\end{array}$ & High & $\begin{array}{l}\text { Medium } \\
\text { High }\end{array}$ & $\begin{array}{l}\text { Combination with standards and labelling, choice of } \\
\text { products with technical and market potential }\end{array}$ \\
\hline $\begin{array}{l}\text { Energy efficiency } \\
\text { certificate or white } \\
\text { certificates }\end{array}$ & Medium & $\begin{array}{l}\text { High } \\
\text { Medium }\end{array}$ & $\begin{array}{l}\text { No long-term experience. Transaction costs can be high. } \\
\text { Institutional structures needed. Profound interactions } \\
\text { with existing policies. Benefits for employment }\end{array}$ \\
\hline $\begin{array}{l}\text { Kyoto Protocol flexible } \\
\text { mechanisms }\end{array}$ & Low & Low & $\begin{array}{l}\text { At the end of } 2012 \text { a limited number of CDM \& Jl was } \\
\text { considered in projects for buildings. }\end{array}$ \\
\hline \multicolumn{4}{|c|}{ Fiscal instruments and incentives } \\
\hline Taxation (on $\mathrm{CO}_{2}$ or fuels) & Low & Low & $\begin{array}{l}\text { Effect depends on price elasticity. Revenues can be } \\
\text { earmarked for further energy efficiency support schemes. } \\
\text { More effective when combined with others }\end{array}$ \\
\hline $\begin{array}{l}\text { Tax exemptions/ } \\
\text { reductions }\end{array}$ & High & High & $\begin{array}{l}\text { If properly structured, stimulate introduction of efficient } \\
\text { equipment in existing and new buildings. }\end{array}$ \\
\hline Public benefit charges & Medium & High & $\begin{array}{l}\text { Success factors: independent administration of funds, } \\
\text { regular monitoring \& feedback, simple design }\end{array}$ \\
\hline $\begin{array}{l}\text { Capital subsidies, grants, } \\
\text { loans }\end{array}$ & High & Low & $\begin{array}{l}\text { Positive for low-income households, risk of free-riders, } \\
\text { may induce pioneering investments }\end{array}$ \\
\hline \multicolumn{4}{|c|}{ Support, information and voluntary actions } \\
\hline $\begin{array}{l}\text { Voluntary and negotiated } \\
\text { agreements }\end{array}$ & $\begin{array}{l}\text { Medium } \\
\text { High }\end{array}$ & Medium & $\begin{array}{l}\text { Can be effective when regulations are difficult to } \\
\text { enforce, combined with financial incentives, and threat } \\
\text { of regulation }\end{array}$ \\
\hline $\begin{array}{l}\text { Public leadership } \\
\text { programs, procurement } \\
\text { regulations }\end{array}$ & $\begin{array}{l}\text { Medium } \\
\text { High }\end{array}$ & $\begin{array}{l}\text { High } \\
\text { Medium }\end{array}$ & $\begin{array}{l}\text { Can be effectively used to demonstrate new technologies } \\
\text { and practices. Mandatory programs have higher potential } \\
\text { than voluntary ones }\end{array}$ \\
\hline $\begin{array}{l}\text { Education and } \\
\text { information program }\end{array}$ & $\begin{array}{l}\text { Low } \\
\text { Medium }\end{array}$ & $\begin{array}{l}\text { Medium } \\
\text { High }\end{array}$ & $\begin{array}{l}\text { More applicable in residential sector than commercial. } \\
\text { Best applied in combination with other measures }\end{array}$ \\
\hline $\begin{array}{l}\text { Detailed billing and } \\
\text { disclosure programs }\end{array}$ & Medium & Medium & Success conditions in combination with other measures \\
\hline
\end{tabular}




\section{Assessment of Policy Instruments for Reducing Greenhouse Gas Emissions from Buildings - UNEP SBCI - CEU}

This publication reviews and assesses the policy instruments available worldwide for greenhouse gas emission from buildings, which contribute on average to $30 \%$ of greenhouse gas emissions. There are many proven ways to reduce the energy use in new and existing buildings, but experience shows that this will not happen without intervention from policy makers. This study presents the qualitative and quantitative experiences from different kinds of policy tools applied in countries all around the world.

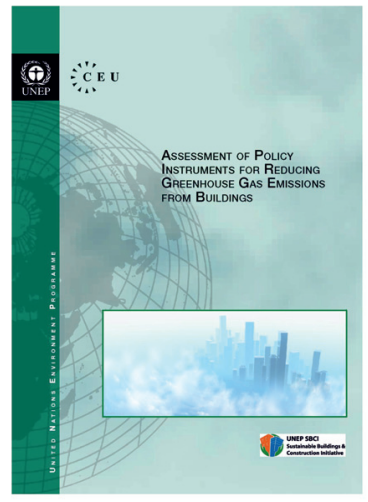

This category of policies can be divided into regulatory-normative and regulatory-informative instruments. Some of the instruments, such as building codes, prescribe a certain standard for producers whereas others, such as mandatory labelling, stipulate just the provision of information to the users, who may decide not to follow the advice.

Numerous case studies have shown that standards and obligations are usually effective in the building sector. However, their effectiveness can be hampered by poor enforcement, which is a major obstacle to real effectiveness in several countries (Ürge-Vorsatz et al., 2007). Other limits to the effectiveness of these instruments are related to rebound effects.

In order to remain effective, control and regulatory instruments have to be monitored, evaluated and updated or revised regularly in accordance with technological developments and market trends (as recently it has been done for energy-saving policies). Unfortunately, regulatory instruments are much more applicable and easy to enforce in new than in existing buildings, and may be insufficient to promote the adoption of green innovations in existing buildings.

\subsubsection{Economic and market-based instruments}

Economic instruments for sustainability improvements in buildings are based on market mechanisms and usually contain elements of voluntary action or participation which are often initiated or promoted by regulatory incentives (UNEP, 2007). 
As most economic or market-based instruments, they are rather new in the building sector and have been implemented only recently, mostly in developed countries (deCanio, 1998, Häkkinen \& Belloni, 2011). Ex-post evaluations are rarely available for these policies.

The instruments in this category of policies differ considerably in their form, aim, and emission reduction effectiveness. These instruments include energy performance contracting, cooperative procurement, efficiency certificate schemes and credit schemes. In addition, flexible mechanisms (CDM and Jl) according to Kyoto protocol belong to this category of policies. Unfortunately, the small opportunity of energy saving in the building sector and the fragmentation of the effects of different measures require developing new instruments to fit the characteristics and opportunities of buildings.

\subsubsection{Fiscal instruments and incentives}

These instruments include energy or carbon taxes, tax exemptions and reductions, public benefits charges, and capital subsidies, grants, subsidised loans and rebates. They target energy consumption and upfront investment costs. Examples of their cost-effectiveness include tax exemptions, public benefits charges, and subsidies.

Taxes can reinforce the impact of other instruments such as standards and subsidies, affecting the building life cycle and making investments for green innovations more profitable. They offer governments the possibility of investing tax revenues into green-building improvements. A challenge in their implementation remains low price-elasticity of demand, and dependence on how households spend their disposable income and the availability of substitute technologies.

Grants and subsidies are well suited to low-income households, which tend not to make investments in energy efficiency even if they have access to capital. By providing unconditional grants and subsidies, governments can provide direct capital rather than access to capital (UNEP, 2009). Grants are also best suited to encourage innovators and small businesses who would like to invest in R\&D, but find it difficult to access capital from the market.

For middle- and upper-income households, preferential loans may be more appropriate to carry out sustainability improvements. For example, KfW, a German development bank, launched preferential loans using a double-edged mechanism to finance them through public tax exemption for investments in efficiency projects coupled with direct public subvention (UNEP, 2009). For largescale "greening" efforts in commercial buildings, the introduction of reduced fees and waivers can significantly help the uptake of sustainable measures.

Ordinarily, construction costs are significant barriers to sustainable innovations as they are non-trivial and have to be paid up-front. Reducing or 
waiving fees if a building meets certain sustainability criteria helps to stimulate sustainable building. Another effective measure for sustainable building is a reduction in property taxes tied to the sustainability performance of buildings.

\subsubsection{Support, information and voluntary actions}

This category of instruments includes voluntary certification and labelling programmes, voluntary and negotiated agreements, public-leadership initiatives, awareness raising and education, as well as detailed billing and disclosure programmes. Examples of these are the sustainability assessment labels extensively discussed in Chapter 3.

Appliance efficiency standards and labels are also important in "greening" the building sector (Berardi, 2011). Among the oldest and most comprehensive of these instruments there are the U.S. Federal Minimum Efficiency Performance Standards programme and the U.S. Energy Star endorsement label programme.

The public sector has a leading role in using these kinds of policies to show their effectiveness. Public leadership programmes can reduce costs in the public sector and provide demonstration of new technologies. With respect to education and training, it is evident that the sustainability transition of the building sector necessitates a large number of skilled professionals: this suggests the importance to increase the number of professionals with the expertise in the development and implementation of sustainability codes and standards on green building design, energy auditing, labelling and certification, energy efficient operation and management.

\subsection{Efficacy of Policies and their Combinations}

The analysis in SBCI (2007) concluded that regulatory and control measures are probably the most effectives and most cost-effectives policies for sustainable buildings. However, grants and rebates have demonstrated to be necessary in any country to overcome the first cost-barrier of sustainable innovations. Tax exemptions appeared to be particularly effective tools among fiscal instruments (deCanio, 1998). However, subsidies, grants and rebates generally have a high cost for the society (UNEP, 2007). Financial instruments are typically more effective if they are applied together with other instruments, such as labelling combined with tax exemptions.

The results of $\mathrm{SBCl}$ (2007) have shown the high effectiveness and costeffectiveness of regulatory instruments compared with economic ones. These findings are probably specific of the building sector, considering its organisational and information barriers for the transition to sustainability (Chapters 5 and 7). In 
fact, regulatory and control instruments are particularly effective in addressing two main key barriers to sustainability: transaction costs and market failures.

Recent studies have shown the importance of considering combinations of policies to result in synergistic impacts and higher savings. For example, appliance standards are often combined with labelling and rabbet to give incentives for investments beyond the minimum levels required by the standard (UNEP, 2009). Also, labelling of sustainable products can be critical in enabling financial incentives such as loans, subsidies and tax credits to be more effective (Berardi, 2011).

For example, in the U.S. building market, mandatory sustainability regulations have recently been coupled with voluntary labels and tax credits for both manufacturers and consumers (Kubba, 2010). These combinations help eliminating the least efficient products. Similar policies are common in many European countries.

Special enabling factors to support measures for green buildings are:

- Financial assistance or funding mechanisms with technical assistance and training;

- Regulatory measures, such as mandatory audits and incentives together with demonstration projects and information to build trust;

- Monitoring and evaluation continually based on new baseline data;

An integrated policy framework that combines regulatory instruments, such as standards or mandatory audits in certain buildings, capacity-building, training and information campaigns and demonstration projects coupled with incentives can more likely be effective.

\subsection{Policies for Sustainable Buildings in Italy}

This section describes policies for sustainable building in Italy. The framework of policies for sustainable building which has been reviewed in Sections 8.1 and 8.2 is used to discuss Italian policies for sustainable building. In particular, the effectiveness of Italian policies is discussed below. Later, few suggestions for increasing the diffusion of green innovations in Italian buildings are reported.

Adjusting the priorities of policies to the peculiarities of each context is particularly important. For this, the recognition of barriers to the adoption of green innovations in real case studies is particularly useful. The Italian projects described in Chapters 6 and 7 have highlighted specific barriers to green innovations: low motivation of stakeholders, low request from clients, high transaction costs, difficulties in re-organising the building process and interaction between stakeholders. 
As seen in Section 8.2, regulatory and control instruments have shown to be the most effective policies around the world. In Italy, these policies are widely used too and, in fact, national regulations are progressively requiring an increasing energy efficiency level of buildings under the pressure of European policies. The progressive reduction of the energy consumptions in buildings and the progressive increase in their sustainability levels show that European laws are frequently upgrading the requirements in terms of sustainability of buildings.

The requirements of new regulations were frequently cited during the interviews to stakeholders of the case studies considered in previous chapters. All the stakeholders considered new laws about sustainability of buildings as highly stringent. Moreover, in several occasions, stakeholders were confused about the measures to take. In this sense, case studies showed that the performance-based laws which have been adopted in previous years should be supported by notes with practical solutions and examples of sustainable building.

The case studies showed that a low interest within the local government for the sustainability of the buildings existed. In Italy, the distance between national regulations and local regulations should surely be reduced in future policies. This could happen by imposing the local governments to adopt sustainability plans and regulations for green innovations and sustainable buildings in the local communities.

Another aspect related to local regulations and actions is the absence of policies of control for sustainability measures that are effectively adopted in the building and for post occupancy evaluations. This situation should be removed too, as a frequent activity of control over the actions taken in building sites could largely favour the adoption of green innovations in buildings and, hence the transition to sustainability of the building sector. Moreover, requests for energy post-construction assessments are increasing worldwide after the limits of energy simulation and preconstruction modelling have been shown.

Economic- and market-based instruments are actually absent in the building sector in Italy. The recent financial crisis has made more critical the access to subsidies for green innovations for sustainable buildings. Moreover, the disperse consumption which characterises the building sector has prevented the diffusion of Kyoto mechanisms. In fact, as already seen at European level, Clean Development Mechanism or White/Green certificates are not suited for application in the building sector in Europe where the consumption are dispersed and fragmented in many buildings which lack of a common management $(\mathrm{SBCl}, 2007)$. The lack of economic and market instruments have been highly criticised during interviews, especially by general contractors who declared their difficulties for the over costs of sustainable innovations. 
In Section 8.2, the high public cost of subsidies has been criticised. Considering the international and national crises of recent years, other instruments have hence been considered to help the diffusion of green innovation and the transition towards sustainability of the Italian building sector.

Fiscal instruments are diffused in the Italian building sector. Since 2009, a vast program of fiscal instruments allows homeowners to compensate $55 \%$ of the cost of green technologies from annual taxes. This policy has been designed for owners that want to retrofit their houses. The result of this policy has been significant as it allowed substituting $2.5 \%$ of heat boilers with high-energyefficient boilers in 2010 (ANCE, 2011). Between 2007 and 2009, more than 590.000 requalification projects for existing buildings have applied to fiscal incentives (ANCE, 2011), with a total investment of $8 \mathrm{M} €$. These data show the success of policies of fiscal instruments in Italy. However, looking in detail at the incentives that have been granted, $94 \%$ of actions have been taken by singleperson owners of single houses. This shows that there is a request for fiscal instruments, which help promote interventions in multi-family buildings.

Moreover, as the construction of new buildings still represents a significant part of the investment in the building sector, a specific fiscal policy should be created to help the general contractors in the adoption of sustainable innovations in new buildings. During the interviews reported in Chapters 6 and 7, fiscal measures emerged that reduce the tax for the general contractor according to the sustainability of the construction; these measures could surely represent an incentive for sustainable buildings.

The last category of policies which has to be considered for "greening" the Italian building sector is that of information and voluntary actions. Public leadership programs are still rare in Europe. An impulse to disseminate a culture of green innovations for sustainable buildings has been due to the sustainability assessment systems. Unfortunately, the low diffusion of sustainability labels in case studies and more in general in many European countries Italy represents a limited driver to the diffusion of green innovations. In fact, it prevents wider recognition of the advantages of sustainable buildings. A difficulty in recognising the experience and qualifications of actors has also emerged in the case studies. This could be solved by incentivising specific programs which signal actors and actions of the increasing "green building economy".

Finally, an increase in communication about sustainable building and more incentives for the diffusion of assessments, labels and certifications related to sustainability are necessary. 